\title{
Tuore ja monisärmäinen runoilijakuva Saima Harmajasta
}

\section{Ritva Ylönen, Saima Harmaja: Sydänten runoilija 1913-1937. Helsinki: SKS. 2019, 298 S.}

Saima Harmaja (1913-1937) on monien tuntema runoilija, ja hänen runonsa ovat olleet etenkin nuorten suosimia. Tunnettuuteen on vaikuttanut se, että Harmaja kuoli tuberkuloosiin sangen nuorena. Lisäksi hänen äitinsä Laura Harmaja valikoi ja toimitti pian tyttären kuoleman jälkeen teoksen Kootut runot sekä runoilijankehitys päiväkirjojen ja kirjeiden valossa (1938). Saima Harmajan runot on siitä pitäen nähty nuorena kuolleen runotytön elämäntarinan varjostamana.

Ritva Ylönen tarttuu Saima Harmajan elämäntarinaan uusin ottein. Hän kritisoi Laura-äidin harjoittamaa sensuuria päiväkirjojen osalta ja asettuu kriittiseen suhteeseen myös Kaarina Helakisan Saima Harmaja: Legenda jo eläessään -elämäkertaan (1977) nähden. Ylösen näkökulma on tuore osin siksi, että hän on etsiytynyt alkuperäisten päiväkirjojen ja arkistolähteiden sekä muun muassa Saima Harmajan salakihlatun, Jaakko Holman kanssa käydyn kirjeenvaihdon äärelle.

Pääosin Sydänten runoilija -elämäkerran uudenlainen näkökulma perustuu Ylösen lukukokemuksiin. Harmajan runot ja eritoten päiväkirjat ovat olleet hänelle tärkeitä jo nuoresta lähtien. Ylösen omiakin elämänvaiheita värittävät suuret menetykset, mutta Harmaja on ollut hänen kirjallinen kumppaninsa myös nuoruuden kasvukivuissa ja rakkauselämän kiemuroissa. Ylönen viittaa lisäksi useaan otteeseen Suomalaisen Kirjallisuuden Seuran tekemään lukijapalautekeräykseen. Otteet osoittavat, että nykynuoretkin ovat löytäneet Harmajansa.

Ylösen kuvaamana Saima Harmaja osoittautuu varhaiskypsäksi ja pikkuvanhaksi, mutta yhtä tarvitsevaksi ja huomiohakuiseksi kuin monet muutkin teinit. Yksinäisyyden tunnot, itkuisuus ja ajoittainen raskasmielisyys rasittivat Harmajaa. Toisaalta hän osoittautuu päällepäsmäriksi, joka harrasti roolileikkejä, näyttelemistä ja raisuja ulkoleikkejä. Harmaja oli nykytermein ajatellen haasteellinen lapsi ja nuori - mutta ennen kaikkea elinvoimainen ilmestys, joka ei vain istunut haaveilemassa tai kirjoittamassa runojaan vaan oli myös toimelias, puhelias, sanavalmis, aikaansaava ja laajakirjoisen tunteikas. Tyttöä kiinnostivat varhain pojat, ja hän oli sisäistänyt käsityksen, jonka mukaan poikays- 
tävä olisi hyvä olla olemassa. Samalla Harmaja oli myös tietoinen ja innostunut naisasiasta, muun muassa kirjailija ja kansanedustaja Hilda Käkikoskesta.

Nuori runoilijanalku pakeni vaatehuoneeseen kiristelemään hampaitaan, rukoilemaan ja purkamaan liikutustaan, kuten Ylönen kirjoittaa. Mitä ilmeisimmin tunteiden osoittaminen ja ilmaisu eivät olleet sallittuja ainakaan siinä mitassa kuin temperamentikas Harmaja niitä osoitti. Häntä kasvatettiin hyväksi tytöksi ja naiseksi, porvarillisen ja suomenmielisen kodin periaatteiden mukaan. Häntä suojeltiin ja vaalittiin, mutta epäilemättä myös rajoitettiin ja säänneltiin ajan tapojen mukaan. Harmajan vakava oireilu ja sairastelu alkoivat jo varhaisessa teini-iässä, eikä kyse ollut alun alkaen keuhkotaudista. "Heikkohermoisuus" oli diagnoosina tytön lukuisille psykofyysisille oireille, jotka Ylösen mukaan kielivät vakavasta ahdistuneisuudesta. Jo 14-vuotiaana Harmaja passitettiin lepokotiin hoitamaan hermojaan.

Ylösen kirja on sujuvasanainen, dynaamisesti etenevä ja kompakti kokonaisuus. Se noudattaa pääpiirteissään Harmajan elämän kronologiaa, mutta myös ennakoi ja käyttää takaumia. Luvussa kaksi luodaan jo eräänlainen kokonaiskatsaus Harmajan elämänvaiheisiin. Sydänten runoilijan suurin anti on, että se luo konkreettisen ja lihallisen ymmärryksen nuoren tytön elämästä, joka oli yhtä aikaa dramaattinen ja monisärmäinen sekä haastava ja traaginen. Harmaja ei Ylösen kirjan jälkeen ole enää vain se nuorena nukkunut eteerinen runoilijansielu, vaan tyttö ja nuori nainen täynnä elämää sen kaikessa moneudessaan. Sydänten runoilijassa piirtyy vaikuttava kuvaus tytöstä, joka säätää ja sählää mutta ennen kaikkea luo sekä runoutta että itsestään runoilijaa jo varhain. Runous toimi ilmaisuväylänä, jollaista ei muuten ollut tarjolla.

Entä sitten Harmajan runot - kokoelmat, jotka ilmestyivät vuosien 1932-1937 välillä? Teemu Keskisarjan taannoinen Aleksis Kivi -elämäkerta (Saapasnahkatorni 2018) vältteli kajoamista Kiven tuotannon analyysiin tai tulkintoihin. Ylönen siteeraa Harmajan runoja, osin kokonaisina mutta ajoittain vain viittaa niihin tai tiivistää niitä omin sanoin. Kokonaiskuvaa Harmajan runoista ei saada, ja runovalinnat näytetään poikkeuksetta osoituksina Harmajan elämäntilanteista aivan suoraan, mikä on toki perinteinen elämäkertojen ongelma. Harmajalainen runokieli antaisi runsaasti mahdollisuuksia myös muuhun, yhtenä osoituksena tuotannossa tapahtuva muutos kohti suorasanaisuutta, joka käy ilmi postuumisti ilmestyneessä Kaukainen maa -kokoelmassa (1937). Mielestäni Ylösen runovalikoima ei esittele Harmajan runotaitoja niiden täydessä mitassa ja ulottuvuudessa. Elämäkerrassa voi toimia myös toisin, mikä ilmenee havainnollisesti Leena Kirstinän kirjoittamassa Kirsi Kunnas -elämäkerrassa (Sateessa ja tuulessa 2014).

Saima Harmaja ei ole ollut runoudentutkimuksen agendalla vuosikymmeniin. Pitäisikö olla? Jos runoudentutkimusta ajattelee etenkin lukukokemusten näkökulmasta, kuten Ylönen tekee, vastaukseni on kyllä. Ylösen kirja herättää tarpeen paneutua Harmajan runoihin nykynäkökulmista, esimerkiksi tun- 
nustuksellisuuden valossa, josta aiheesta Anna Hollsten on kirjoittanut tämän lehden palstoilla (Avain 2/2014). Kokemuksellisuus, tunteet ja aikansa tarjoamat kielen keinot ovat yhdistelmä, josta niin Harmajan kuin muidenkin lukijoiden suosikkien kuten Eino Leinon, Tommy Tabermanin tai Heli Laaksosen runot kumpuavat. Niiden funktio ei ole niinkään ollut radikaali uudistaminen vaan pikemminkin tarttumapinnan tarjoaminen lukijakunnalle. Sitä Saima Harmajan tuotannossa ilmenee lukuisin keinoin, jotka suhteutuvat ilmestymisaikaansa, sen rajoihin ja mahdollisuuksiin.

Siru Kainulainen 


\section{Abstracts}

\section{Karoliina Lummaa}

\section{How to read waste \\ Being and meanings of unwanted matter in Jukka Viikilä's poetry}

The article examines Jukka Viikilä's poems about waste and other unwanted matter in his collections Runoja (Poems, 2008), Runoja II (Poems II, 2010), and Ensyklopedia (Encyclopedia, 2011), a collection jointly written by Viikilä, Janne Nummela and Tommi Nuopponen. Viikilä's poetry addresses the cultural, social, and experiential meanings and effects of waste, trash, filth, pollution, poisons, and fecies, as they emerge, pile up, and are managed both practically and conceptually in our society and everyday living. Thematically, the article focuses on classification, ontologies, and management of wastes. As many of Viikilä's poems are actually lists of substances and objects, this formal feature is also discussed in the study.

Waste studies is a humanistic, multidisciplinary approach for researching histories, social practices, philosophies, and aesthetics of waste. While utilizing this field to analyse Viikilä's poetry, the article also discusses the apparent tensions between constructionist and new-materialist ideas in waste studies.

As the article concludes, Viikilä's waste poetics represents an aestheticalexperiential understanding of waste and offers its readers an opportunity to contemplate material excess and surplus in a world where more and more things are produced, consumed, and discarded.

Keywords: waste, Waste Studies, Material Ecocriticism, Jukka Viikilä 


\section{Peeping of a whistle, tootling of a shepherd's flute?}

The connections of Otto Manninen's poems "Pellavan kitkijä" and "Luistimilla" to the Finnish rhyming folksong tradition

This article shows that the poetry of Otto Manninen (1872-1950) relates to the tradition of folksongs that has generally been viewed as shallow. In the article, the relationship between Manninen's poetry and Finnish folksongs is examined specifically through rhyming folksongs (rekilaulu) that follow the Finnish rhyming couplet metre. At the end of the 19th century, these songs were the dominant folksong genre in Finland and authors and poets became interested in them in the 1890s. In earlier research, Manninen's poetry has been seen in opposition to songlike and melodious poetry, particularly as represented by Eino Leino. Manninen's poetry has been examined in the light of the poetics of symbolism, and its constructive and cryptical features have been emphasized. Two poems from Manninen's first collection Säkeitä (Verses, 1905) are analysed in detail. The poems "Pellavan kitkijä" (Harvest of flax) and "Luistimilla" (On skates), had both already been published earlier, in 1897 and 1900. The poems are compared to folksongs of oral folklore (with reference to the folklore collection notes in the archives of the Finnish Literature Society). Particular attention is paid to the strophic form and how the poems reproduce and vary the formulas of oral folklore. In the case of the poem "Luistimilla", the question of rhythm is also touched on. Antti Rytkönen's poem "Järven jäällä" (1900) (On an icy lake) and some materials from Manninen's archive are also discussed.

Keywords: study of poetry, Finnish rhyming folksongs, stanza, formula, intertextuality, manuscripts, Otto Manninen

Päivikki Romppainen

\section{Dialogism, sublime and macabre in Paavo Rintala's novel Aika ja uni}

This article discusses how autobiographical memories, general histories and sublime, macabre or grotesque elements shape the narrator figure in Paavo Rintala's novel Aika ja uni (1993). In Rintala's late prose work from 1987 onwards, the narrator conducts a strong inner dialogue with his memories from different periods of his life. By using Mikhail Bakhtin's concept of dialogism and Jens Brockmeier's theories of autobiographical memory, I demonstrate how the 
heterogeneous strands of individual and historical memory are woven together through the creation of tropes that are characterized by inner tensions. By analyzing the archetypal figure of the soldier, I show how it both combines and transgresses the dichotomies between the positions of the victim and the perpetrator. Furthermore, the narrator combines sublime tropes (martyrdom) with macabre or grotesque ones (an ageing, hunchback Christ-figure) in his narration of the traumatic histories of the $20^{\text {th }}$ century. As a result, no clear narrative conclusion or definitive interpretation of the narrator - or the histories - can be achieved. This may, in turn, provoke readers into taking a more active ethical role in their reading of the tensions between the centripetal and centrifugal forces in the text.

Keywords: dialogism, autobiographical memory, sublime, macabre, historical trauma, ethical reading, Paavo Rintala

\section{Hanna Meretoja}

\section{Metanarrativity and Narrative Agency}

In this article, I argue that a crucial feature of postpostmodernist contemporary fiction is metanarrativity. In contrast to earlier approaches, I propose that the following two aspects are integral to metanarrativity: the way in which metanarrative fiction reflects not only on its own narrativity but also on the significance of narratives for human existence and on the functions of narratives in culture and society. I theorize metanarrativity in relation to the concept of narrative agency. Our narrative agency consists of our ability to use, interpret and reinterpret narratives that are culturally available to us, to analyse and challenge them and to make choices over how we narratively interpret our lives and the surrounding world. I propose a model that articulates three central dimensions of narrative agency: narrative awareness, narrative imagination and narrative dialogicality. In dialogue with the concepts of metannarrativity and narrative agency, I analyse Siri Hustvedt's novel The Summer Without Men (2011). Finally, I discuss how the dialogical space opened up by reading together can promote narrative agency.

Keywords: metanarrativity, narrative agency, narrative awareness, narrative imagination, narrative dialogicality, Siri Hustvedt, The Summer Without Men 


\section{Tule jäseneksi}

\section{Kirjallisuudentutkijain Seuraan!}

Jäsenenä saat seuran julkaiseman Avain-lehden neljästi vuodessa sekä oikeuden osallistua seuran järjestämiin seminaareihin ja muihin tilaisuuksiin.

Kirjallisuudentutkimuksen aikakauslehti Avain

Kirjallisuudentutkimuksen aikakauslehti Avain on tapa päästä sisään kirjallisuudentutkimuksen maailmaan. Se tarjoaa tieteellisten artikkelien, tutkimus- ja kirja-arviointien lisäksi erilaisia puheenvuoroja kotimaisesta ja ulkomaisesta kirjallisuudesta ja sen tutkimuksesta. Lisäksi se pyrkii herättämään keskustelua kirjallisuudentutkimukseen liittyvistä ajankohtaisista aiheista.

Avain jatkaa kirjallisuudentutkimuksen äänitorvena seuransa 90 vuoden kokemuksella.

Neljästi vuodessa ilmestyvä Avain on Kirjallisuudentutkijain Seuran lehti, jonka saa seuran jäsenetuna maksamalla jäsenmaksun 48 euroa (perustutkinto-opiskelijat, apurahatutkijat, työttömät ja eläkeläiset 27 euroa) Seuran tilille FI90 800012014734 45. Viestikenttään merkitään jäsenen nimi ja osoite lehden postitusta varten.

Ilmoittamalla sähköpostiosoitteesi seuran sihteerille Marianna Koljoselle (sihteeri.kts@gmail.com) pääset mukaan myös seuran postilistalle kts@uta.fi, jolla tiedotetaan alaan liittyvistä tapahtumista. Listaa käytetään myös tiedonhankintaan, sekä keskusteluun kirjallisuutta ja kirjallisuudentutkimusta koskevista ajankohtaisista aiheista.

Lisätietoja seurasta: http://pro.tsv.fi/skts/ 